\title{
SOCIO-PEDAGOGICAL PROBLEMS OF MODERN STUDENTS' ATTITUDE TOWARDS SCHOOL
}

\section{Summary}

\section{Introduction}

One of society's quality development conditions is a good school. The good school involves a positive sense of self, students' joy to learn and teachers 'wish to work in a creative manner, parents readiness arrive at the school.

Human-pedagogical school theory (Gudjons, 2007) sees the school as an influential factor in the mutual relation of social culture, social economy and politics. It is impossible to define the school in the modern trendy society only on the basis of learning process because it is closely followed "by upbringing (as development of personality), compensation (as equalization of social behaviour deficit) and security function” (Gudjons, 2007).

\section{Aim of the Study}

To analyse the socio-pedagogical problems and causes of students'attitude towards school

\section{Materials and Methods}

The study uses materials of audit statement "General Educational System Realisation in Correspondence with the Goals Set" by the State Control of the Republic of Latvia, interviews with 12 principals of schools, analysis of minutes of 54 visited lessons, questionnaires to 828 students.

\section{Results}

Analysis of the results revealed uneven students' attitude towards school which is determined by the attitude towards learning, classmates and teachers. A special problem is self-evaluation of study achievements because these skills are not developed to a satisfactory level in students. The attitude towards school is determined also by fragmentary education, insufficient facilitation of organization of students' self-education.

\section{Conclusions}

Lack of learning motivation among students and upbringing fragmentarism at school negatively influence the formation of students'attitude towards school.

During adolescence students lack self-confidence and purposefulness, they do not wish to think and commit to work during the learning process because learning has not become personally significant for most students, and thus their pedagogical needs are not satisfied.

Key words: school, students' attitude towards school, self-confidence.

\section{Introduction}

One of the conditions for a quality development of society is good school. The good school involves a positive sense of self, students' joy to learn and teachers' wish to work in a creative manner, parents readiness come to school.

Human-pedagogical school theory (Gudjons, 2007) sees the school as an influential factor in the mutual relation of social culture, social economy and politics. It is impossible to define the school in the modern trendy society only on the basis of the learning process because it is closely 
followed "by upbringing (as development of personality), compensation (as equalization of deficit of social behaviour) and security function" (Gudjons, 2007).

Modern school, as organized by the state or individuals, is an institution with multiform structure for complex and systematic implementation of students' balanced development and socialisation functions in interaction students - teachers - parents - society. This means that the limelight of the school includes the internal and external contacts. Usually the state shifts focus on the internal life of school instead of external contacts which should be changed accordingly. For example, by implementing 9-year education in Latvia, no institution can inform how many students have not acquired the obligatory education. This is an issue of school's external contacts as well as of mutual relation and succession of the system of educational institutions. This is also an issue of external contacts of the school which directly affects the internal life of the school. The state has stipulated that the student is in one community of students from form 1 to 4 . Then, in form 5 , the community of students is changed. Community of forms 5 and 6 starts forming under the leadership of very good class teachers and teacher team (if any) which is much more difficult than in the first 4 forms. Upon finishing form 6, part of the students goes to grammar schools. Students' communities in forms 7 are again new but students' need to belong to a community of equals increases. (Крайг, 2003) Within the communities of equals, students implement the act of learning thus acquiring the experience of working together, being helpful, responsive, acquiring the skills of cooperation and organizing work during lessons and outside them. The learning environment in classes, especially forms 5-9, should be formed as educational, influencing the person in a positive manner. This can be done by students in cooperation with teachers in a longer period of time. Since the communities of forms 5 to 9 often change, these classes require special attention in many schools. In a class environment, mutual relation between the students and teachers is one of the most significant factors for the development of personality, especially during lessons. There is no acquisition of education suitable for this age of students organized for teachers-to-be during studies at higher education institutions, therefore no new skilful teachers, class teachers enter these classes. As a result, school praxis in a group of adolescents in forms 5-9 has current socio-pedagogical problems.

For now, both pedagogues and all student families can think in more optimistic terms of a better school now and in the future because the government has announced the education as one of its priorities. Hopefully the ideas will be followed by good deeds: development of ideas of humanpedagogy (cooperation) at schools and society on the whole facilitated in practice, respect and mutual trust will be formed.

\section{Aim of the Study}

To analyse the socio-pedagogical problems and causes of students' attitude towards school.

\section{Materials and Methods}

The study uses materials of audit statement "General Educational System Realisation in Correspondence with the Set Goals" by the State Control of the Republic of Latvia, interview with 12 principals of schools, analysis of minutes of 54 visited lessons, questionnaires to 828 students.

Socio-pedagogical problems of students' development are related to mutual relations of students. „Personality is oriented towards choice instead of orders. Then, a space opens for thoughts, feelings, activity and initiative develops. Such personality treats the communication partner as an equal. This forms a basis for tolerance (Meikšāne, 1998). As a result, cooperation of students $\leftrightarrow$ students is natural and they look for friends among peers. Friendly mutual relationship is one of the 
basic conditions for students' joy when going to school. Out of the 12 interviewed principals, 11 brought students' meeting with class-mates as the most important factor for their attitude towards school. This principals' opinion corresponds to the students' opinion. Out of the questionnaires completed by 828 students, 657 (79\%) stated that they wish to cooperate with class-mates at school. $171(21 \%)$ students respond that they do not have this wish. There is a large amount of students lacking friends, common interests, or probably there exists even mockery of peers. According to teachers, communication of peers shows friendship, perfection of communication and cooperation skills. Students are used to conflicting but these are seldom solved by physical violence.

The social environment of the school is feminised; the teachers are tired because of overload. Thus teachers lack joy of work every day, which then influences also the students. There are schools where no male teachers work. This limits boys' communication skills.

As evaluated by principals, interesting learning work takes the second place in students' attitude towards the school. During previous years in some schools, a materially technical base has improved; information technology in various forms is available at lessons, the teachers work with variety. Of 828 students, 719 (87\%) wish to learn something new, interesting. Learning at school is a student's activity of personal importance within the sphere of professional communication. Students' learning is a means of improvement of personal experience only if their needs are satisfied. These needs are named by I. Maslo as students' pedagogical needs:

$\Rightarrow \quad$ need for love and security;

$\Rightarrow \quad$ need for new experience;

$\Rightarrow \quad$ need for praise and appreciation;

$\Rightarrow \quad$ need for responsibility and independence;

$\Rightarrow \quad$ need for clearness and interrelation.

Satisfaction of these needs is necessary starting from the age of 6-10 years (Maslo, 2006).

Students' inborn need to find out about themselves and the world should be further developed also during the work after lessons. In our schools, cognition activities, which are poorly organized, form a huge reserve for development of students' interests outside lessons. Only 124 (15\%) enquired students respond that they wish to take active part in hobby groups after lessons. There are several assumptions for explaining this phenomenon: 1) students get tired during lessons and do not wish to continue any intellectual work; 2) there are no interesting offers according to the contents and form; 3 ) there are no suitable rooms and materials for interesting activities. This problem refers also to cooperation between students and teachers. Of the 12 school principals, 4 respond that students gladly come to school to meet teachers. In turn only 104 (11\%) students express such wish, but 724 (89\%) students do not have such wish. In 2 schools, none of the enquired students would come to school to meet teachers. Also at school, where the principal placed the teacher in the second place as a positive factor for students' attitude towards school, only 3 out of 83 enquired students' express wish to voluntarily meet teachers. Observations at lessons show that teachers work enthusiastically, they are clever and self-denying, but they still basically provide knowledge to students. Therefore the issue is in learning methods because students have no possibility to express themselves, show their understanding or lack of understanding about things and phenomena. "Formation of the student as personality of active subject is influenced by such activity which changes the student's behaviour, carries out the potential not only by external influence but also depending of the product of activity, especially internal productivity of the activity. In the early youth, satisfaction of needs of self-assertion, self expression, evaluation of one's goals and security is very important" (Šteinberga, 1999). Although 17 years of independence have passed, there are teachers who still act 
in an authoritarian manner which does not facilitate formation of students' feeling for freedom, responsibility and independence. People do not feel as owners of the school. The society rearranges itself much faster to equal democratic cooperation relations than the school.

Therefore, quality of the teachers' personality, contents of the teachers' professional activity and methods are significant indicators of the education quality (Terhart, 2007). It is closely related to the product of teacher's activity - satisfaction of the student's needs for cognition and learning skills.

Principals of schools and teachers evaluate the students positively at large, but remarks are made of indisposition of students from classes 7-9 to learn and of frequent absence from lessons.

For evaluation of the quality of students' activities - as the product of the teachers' and parents' work, we chose students' questionnaire having the main factor of student's self-evaluation.

Free, independent, responsible, active personality is the aim of students' education (Špona, 2006). The aim reached by the students' development is characterised by voluntary choice of subjects. Students, when replying to question „Which subjects do you like learning most?” surprise by a very low level of choice.

\section{Results}

Research data for 828 students summed in Table 1.

Table 1. Students' free choice of subjects.

\begin{tabular}{|l|l|l|}
\hline Amount of students & $\%$ & Subject \\
\hline 85 students & $10 \%$ do not choose & any subjects \\
\hline 243 students & $28 \%$ choose & 1 subject \\
\hline 165 students & $20 \%$ choose & 2 subjects \\
\hline 122 students & $15 \%$ choose & 3 subjects \\
\hline 42 students & $5 \%$ choose & 4 subjects \\
\hline 6 students & & 5 subjects \\
\hline 1 student & & 6 subjects \\
\hline
\end{tabular}

The students could freely choose subjects at the questionnaire. Table 2 sums up the free choice of subjects.

Table 2. Priorities of subjects chosen by students.

\begin{tabular}{|ll|l|l|}
\hline \multicolumn{2}{|l|}{ Subject } & Amount of students & $\%$ \\
\hline $1 . \quad$ Maths & 248 & $28 \%$ \\
\hline 2. $\quad$ Sports & 175 & $21 \%$ \\
\hline $3 . \quad$ English & 154 & $18 \%$ \\
\hline $4 . \quad$ Geography & 133 & $16 \%$ \\
\hline 5. History & 131 & $16 \%$ \\
\hline $6 . \quad$ Physics & 107 & $13 \%$ \\
\hline $7 . \quad$ Visual Arts & 96 & $12 \%$ \\
\hline $8 . \quad$ Chemistry & 94 & $11 \%$ \\
\hline 9. Latvian & 91 & $11 \%$ \\
\hline $10 . \quad$ Literature & 89 & $10 \%$ \\
\hline $11 . \quad$ Information Sciences & 71 & $8 \%$ \\
\hline 12. Music & 55 & $6 \%$ \\
\hline and others & & \\
\hline
\end{tabular}

This means that a school could be completed with 328 students where approximately 3 classes would be constituted of students who do not study any subject on free will, but the rest of them 
study only one subject on free will. It is a certain statement of poverty of intellectual, emotional development and development of will in our school. It is hard to talk about balances development of a versatile and harmonious personality. Development for those students is not being diagnosed and corrected, to my mind.

And it happens in time when the basic position chosen for years 2007-2013 of the Ministry of Education is as follows: „, To increase the quality of acquisition of general knowledge, education of value and skills of life..." (Basic Position for Education Development for Years 2007-2013). Section of General Education Law stipulates an aim - ,to create an environment for the development of a creative and comprehensively educated individual, as well as to create an environment for the uninterrupted continuation of the education of students, for the acquisition of a profession, and for an independent orientation in public and State life." (General Education Law).

The research reveals that the quality of students' activities is far from the chosen aims. The students lack aim of learning during lessons, as well as there is no clarity regarding the knowledge, skills and attitudes to be acquired in each class (Audit report).

Why students choose Maths, Sports and English? Is it not a direct influence of market economy to the educational policy?

Students are being oriented towards business, economy in their life together with good knowledge of English and good physical development. Latvian, Literature and Music have an unforgivably low choice. This means that the school neglects the preservation of national culture and further development. Without acquisition of humanitarian subjects, no harmonious formation of a personality, development of systematic and structured thinking is thinkable. However, the visited lessons of Latvian and Literature were all perfect by contents and organization. There is little integration in these lessons with other subjects. This testifies that students are still acquiring the contents of the subjects in isolation from each other, and they get fragmentary knowledge of themselves and the world.

In the visited lessons which were chosen unintentionally for the research, almost half of the lessons included learning and evaluation methods which facilitate cooperation.

The questionnaire testifies that as soon as cooperation requires initiative and activity, the responses differ. To the question, „Do you wish to help class-mates or younger students at learning in school?" only 88 students gave positive answers, but 739 denied their wish. Development of cooperation skills is facilitated by active position of life; wish to be active not only during the obligatory lessons, but also to search a possibility to implement one's abilities also outside lessons. Unfortunately the research showed the disinclination of the majority of students to be active.

Responses to question „Do you wish to participate at work of cleaning the classrooms and the school?” („yes” by 37 respondents, „no” by 791) because once the traditional joint work of school cleaning and work as educational means was ignored as unnecessary without seeing the relation with educational and upbringing process, right after restoration of the independence. Such tendency is very noticeable in Riga and larger towns of Latvia.

Even to a question which seem to be appropriate to the age, ,Do you wish to go to parties?" there is not even a half of positive replies („yes” by 368 respondents, „no” by 460).

Wish to show oneself, compare one's achievements with equals of age is possible at contests and competitions. In turn, participation requires presence of certain traits of character - daring, selfassurance, skills to win and lose. It is clear that it will never be possible to achieve $100 \%$ participation at events where the ability to compete must be shown, however, the following responses allow to doubt the assumption that a student acquires the ability to overcome the difficulties of life and in 
the narrowest meaning - acquires the skills to stand on one's own feet in the labour market:

$\Rightarrow$ Do you want to participate at competitions? ("yes" by 217 respondents, "no" - 611);

$\Rightarrow$ Do you want to participate at sport competitions? ("yes" by 328 respondents, "no" - 500).

For development of communication and cooperation skills, the school will always be a significant factor for students' development, the question arises nor now and the future on the quality of these skills.

Change of pedagogical paradigms has mostly influenced the system of evaluation of results. If the understanding that the contents of the studies bears no function of the aim, but rather facilitation of development of students' personality has become such, slowly turn from words into works, then the sphere of evaluation of students' results and self-evaluation shows a rather uneven development.

Moreover, not only for the students themselves or their parents, but also teachers. First, after restoration of independence of Latvia, the system of evaluation was changed from 5 points to 10 points. There was no and is no scientific justification for this change.

Second, if we look at the real system of evaluation of school's results, then one must establish that the evaluation still is carried out within the interval of six points, only each school and even each teacher has this interval different. Unsatisfactory evaluation starts from 3 , but the highest evaluation $(9,10)$ is to be granted only for achievements which exceed what is expected in the educational programme. Thus it will never be available for those students' whose level of abilities in one or other subject is average, but progress in individual development may exceed that of more capable students. Unofficially it is adopted for treating 6 as the maximum point which indicates the minimum, but satisfactory presence of knowledge in the given subject. Evaluation as psychological and pedagogical phenomenon is complicated because its most significant task is to acquire self-evaluation skills. And the stumbling block is the descriptive evaluation adopted in the primary school, where classes $1-3$ have evaluation without points. Thus in the first three classes, understanding should be achieved of tasks of various levels of difficulty and understanding of criteria which determined one or another evaluation.

Points are the indicators of the acquired skills, not the goal. However, together with the already mentioned, it should be taken into account that interiorization processes start developing in the primary school, therefore the external factors, their type and contents are of huge significance. Therefore the points have also a psychological meaning because it promotes development of attitude both towards knowledge, learning and creates a specific emotional experience which further on determined whether the interest for cognition of a primaryschool-student is preserved or not. Therefore failing to evaluate achievements by points, we arrive to a situation when the elementary school has no meaning for it at all because it does not bear any positive emotions, neither for knowledge, nor for learning.

The research does not express all problems related to evaluation but some interesting tendencies have been noticed. For example, in relation to the possibility to get the maximum evaluation (10 points), replies, as reflected in Table 3, were

Table 3. According to students' evaluation, 10 points can be received in the following subjects.

\begin{tabular}{|c|l|l|l|}
\hline No. & Subject & Yes & No \\
\hline 1. & Sports & 362 & 466 \\
\hline 2. & Maths & 217 & 611 \\
\hline 3. & Biology & 159 & 669 \\
\hline 4. & Literature & 147 & 681 \\
\hline 5. & Latvian & 131 & 697 \\
\hline 6. & History & 130 & 698 \\
\hline 7. & English & 109 & 719 \\
\hline 8. & Chemistry & 88 & 740 \\
\hline 9. & Physics & 60 & 768 \\
\hline & All subjects & 69 & 759 \\
\hline
\end{tabular}
received. 
Replies to the following questions imply that in case the teacher does explain the criteria of evaluation, the students use them. In this field, the research showed the following replies:

$\Rightarrow$ "Do the teachers explain how to evaluate achievements in learning?" ("yes" by 435 respondents, "no" - 72, "sometimes" - 321);

$\Rightarrow$ "Do you evaluate your work at lessons and the acquired skills to use them?" ("often" by 365 respondents, "no" - 448, "never" - 15);

It is impossible to make general conclusions on school's ability or disability to help students acquire the skills of evaluation, but teacher's tendencies to explain the criteria of evaluation and some students' habit to evaluate the acquired skills should definitely be appreciated.

„Evaluation criteria are proposed by the teacher, school or state, but criteria for self-evaluation are chosen by the person himself. Criteria, which are referred to oneself, are important because they provide students with a possibility to involve in improvement of their learning. Students may do that because:

$\Rightarrow$ it is a control over one's learning;

$\Rightarrow$ by creating one's own criteria the student understands the reason for learning;

$\Rightarrow$ self-explained criteria inspires the student to reveal motivation;

$\Rightarrow$ process of creating one's own criteria promotes responsibility.

... At present, evaluation of the external learning process is more dominant in schools instead of internal learning process (Hahele, 2006).

The level of upbringing is different if we evaluate it by students' attitude towards their development - physical, mental, social - attitude towards others, at first - parents, teachers, equals of age, as well as attitude towards studies, state and nature.

It should be noted that a better behaviour of students is present in schools implementing comprehensive educational programs. Students are more polite, more organized during breaks; mutual help between equals of age and students and teachers is present during the lessons. Thus, at a Literature lesson for class 12, when analysing project results of I. Ziedonis' poetry, students analysed their own works freely, openly and with interest and suggested what the teacher should change in the literature learning process in future. The teacher thanked the students for good suggestions for improvement of Literature teaching.

Students' sense of self at school, skills to evaluate their own learning process and results, thus developing self-evaluation and cooperation skills, facilitates students' positive attitude towards school, satisfaction or dissatisfaction with work and life at school.

\section{Conclusions}

Schools are managed by professional principals having good pedagogical education and skills of managing schools.

Many teachers with high professionalism and sense of mission work at schools, and they can significantly improve the cooperation between students and teachers during lessons and outside the lessons thus promoting students' balanced development. Not all schools and classes have environment for educating and developing the personality, especially classes 7 - 9 .

Students' low motivation to learn and upbringing fragmentarism at school negatively influences the formation of students' attitude towards school.

During adolescence, students lack self-confidence, purposefulness, they do not wish to think and commit work to the learning process because learning has not become as personally significant for most students, and thus their pedagogical needs are not satisfied. 


\section{REFERENCES}

1. Audit report "General Educational System Realisation in Correspondence with the Set Goals" by the State Commission of the Republic of Latvia. lrvk@lrvk.gov.lv (24.01.2008.)

2. Basic Position for Education Development for Years 2007-2013. Approved by the Cabinet of Ministers on 27.09.2006, Order No 742.

3. General Education Law, wording as at 08.11.2007, www.likumi.lv (24.01.2008.)

4. Gudjons H. (2007) Pedagogijas pamatatziņas. Rīga: Zvaigzne ABC, 396 lpp.

5. Hahele R. (2006) Pašvērtējums mācību procesāa. Rīga: RaKa, 222 lpp.

6. Maslo I. (2006) No zināšanām uz kompetentu darbību. Rīga: LU, 186 lpp.

7. Meikšāne Dz. (1998) Personības pašizjūta un identitāte. Rīga: Mācību apgāds NT, 203 lpp.

8. Špona A. (2006) Audzināšanas process teorijā un praksē. Rīga: RaKa, 211 lpp.

9. Šteinberga A., Tunne I. (1999) Jauniešu pašizjūta un vērtības. Rīga: RaKa, 131 lpp.

10. Terhart E. (2007) Lehrer. In Buch: Tenorth H. E. \& Tippelt R. (Hrsg.) Lexicon Pädagogik. Weinheim und Basel: Beltz Verlag, S. 786.

11. Крайг Г. (2003) Психология развития. 7- е изд. Санкт-Петербург. Москва: Питер, 988 с.

Prof. Dr. habil. paed. Ausma Špona

Riga Teacher Training and Educational Management Academy

The Centre of Research in Pedagogy

Address: Imantas 7. linija, Riga, LV-1083, Latvia

Phone: +37167808015

E-mail: pzi@rpiva.lv 